\title{
Interpreting "Prior Record" under the Federal Juvenile Delinquency Act
}

\author{
Bradley T. Smith $\dagger$
}

In the juvenile justice system, few issues are as important as whether a minor will be tried as an adult. When a juvenile court waives its jurisdiction and transfers a juvenile to criminal court, the minor faces the possibility of more severe punishment, public exposure, the stigma of a permanent criminal record, and incarceration with convicted felons.

Over the last two decades, legislators at both the state and federal level have responded to a perception of rising juvenile crime by making it easier to transfer minors to adult status. This change is part of a general reassessment of how the criminal justice system handles youthful offenders in the wake of gang violence, child murderers, and senseless school shootings. ${ }^{2}$

$\dagger$ B.A. 1998, Michigan State University; J.D. Candidate 2001, The University of Chicago.

1 See Howard N. Snyder and Melissa Sickmund, Juvenile Offenders and Victims: $1999 \mathrm{Na}$ tional Report 88 (GPO 1999) ("During the 1980's, the public perceived that serious juvenile crime was increasing and that the system was too lenient with offenders. Although there was substantial misperception regarding increases in juvenile crime, many States responded by passing more punitive laws. Some laws removed certain classes of offenders from the juvenile justice system and handled them as adult criminals in criminal court."). Between 1992 and 1997, fortyfive states passed laws making "it easier to transfer juvenile offenders from the juvenile justice system to the criminal justice system." Id at 89 . A number of states during this period "enacted mandatory waiver or exclusion statutes," which require that minors charged with certain offenses be automatically transferred to adult criminal court. Id at 103. See also Barry C. Feld, The Transformation of the Juvenile Court-Part II: Race and the "Crack Down" on Youth Crime, 84 Minn L Rev 327, 357-58 (1999) (noting that the rate of juvenile transfers increased by 68 percent between 1988 and 1992 and that "[t]he pace of legal changes to prosecute more juveniles as adults escalated sharply in the early 1990s"); Michael Finley and Marc Schindler, Punitive Juvenile Justice Policies and the Impact on Minority Youth, 63 Fed Prob 11, 11 (1999) (noting that although juvenile crime declined in the last years of the 1990 s, over forty states passed laws "to allow increased prosecution of juveniles in adult criminal courts"); Robert E. Shepherd, Jr., Juvenile Justice, 9 Crim Just 45, 47 (1994) (noting the increased likelihood that minors will be prosecutedeither as delinquents or as adults after transfer - in federal courts under the Federal Juvenile Delinquency Act). Ironically, at the same time legislation has been making it more likely that minors will be tried as adults, the number of serious violent crimes committed by juveniles has dramatically declined. See Snyder and Sickmund, Juvenile Offenders at 62 (noting a decline by 33 percent in the number of serious crimes involving at least one juvenile offender).

2 A 1998 NBC News-Wall Street Journal poll found, for example, that "two-thirds of Americans think juveniles under age 13 who commit murder should be tried as adults." Jeffrey A. Butts and Adele V. Harrell, Delinquents or Criminals: Policy Options for Young Offenders 1 (Urban Institute 1998). 
This Comment deals with one aspect of this transformation in juvenile law. It examines a recent conflict among federal circuit courts concerning what constitutes a "prior delinquency record," which is one of six factors that courts must consider when deciding whether to transfer a minor to adult status under the Federal Juvenile Delinquency Act ("FJDA"). Some circuits have held that a juvenile's prior delinquency record only includes prior adjudicated behavior. Many of these same courts, however, have read other factors expansively and permitted uncharged and unadjudicated conduct that is excluded from the prior record factor to be examined under one of the FJDA's five remaining factors. Alternatively, one circuit has interpreted prior record expansively to include not only prior adjudications, but prior arrests as well. Ultimately, this Comment suggests that courts should interpret the FJDA to permit the review of both adjudicated and unadjudicated prior arrests as part of the juvenile's prior record, but should exclude from consideration previously uncharged conduct that did not result in an arrest.

Part I of this Comment briefly considers the evolution of the modern juvenile court. Part II then describes the Supreme Court precedent that altered the once informal practices of juvenile courts. Part III discusses the FJDA, and Part IV details the circuit conflict over the meaning of a prior delinquency record. Part $V$ then relies on the text and purpose of the FJDA to suggest that when a court examines a juvenile's prior delinquency record, it should consider prior arrests, but not uncharged criminal conduct.

\section{THE RISE OF THE JUVENILE COURT}

Although this Comment specifically considers the FJDA, it is helpful to understand the backdrop against which Congress drafted that legislation. This, in turn, requires considering what the founders of the first juvenile courts saw as the juvenile justice system's primary goals and responsibilities.

\section{A. Progressive Reforms}

1. Theoretical underpinnings.

The idea that courts should treat juvenile offenders differently from adult criminals took hold during the Progressive movement a century ago. ${ }^{5}$ With the rapid industrialization and urbanization of the

\footnotetext{
318 USC $\$ \$ 5031$ et seq (1994).

4 Id.

5 For a general discussion of the rise of juvenile courts, see Barry C. Feld, The Transformation of the Juvenile Court, 75 Minn L Rev 691 (1991); Anthony M. Platt, The Child Savers: The Invention of Delinquency (Chicago 2d ed 1977); Robert M. Mennel, Thorns \& Thistles: Juvenile
} 
United States came a restructuring of the American family. No longer was the workplace synonymous with the family farm or a person's home.

As a result of these shifts, the concept of the family changed.' The number of children in families declined, and a "more modern concept[ ] of childhood emerged." Children, many Progressives argued, did not simply blossom into adults with a minimal amount of adult intervention. Instead, "[c]hildren were perceived as corruptible innocents whose upbringing required ... physical, social, and moral structure." Parents, particularly women, were to take on a greater role in the supervision and upbringing of children. As an outgrowth of this theory, Progressives suggested that criminal acts by children were not signs of an inherently flawed character; rather, they argued that societal forces and a lack of moral direction were largely responsible for wrongdoing."

Therefore, Progressive reformers asserted that special courts should be established with judges that were cognizant of the malleable nature of children and empowered to intervene and prevent a child from being corrupted, abused, or neglected." This idea drew support from the doctrine of parens patriae, a British theory which held "that it is the state's responsibility to care for the vulnerable, including juveniles and all others who are unable to care for themselves." ${ }^{\text {,12 }}$ The state, the Progressives asserted, "had the inherent power and responsibility to provide protection for children whose natural parents were not providing appropriate care or supervision." ${ }^{13}$ The goal of juvenile

Delinquents in the United States, 1825-1940 (New England 1973) (all outlining the Progressives' role in pushing for a separate juvenile justice system).

6 See Feld, 84 Minn L Rev at 332 (cited in note 1) (noting a "shift of economic functions from the family to other work environments").

7 See Barry C. Feld, The Juvenile Court Meets the Principle of the Offense: Legislative Changes in Juvenile Waiver Statutes, 78 J Crim L \& Criminol 471, 473 (1987) (noting how a "a shift of economic functions from the family to other work environments modified the role of women and children").

8 Id at 474.

9 Id.

10 Id at 475 (noting how the Progressives' approach of attributing “criminal behavior to external antecedent forces rather than to deliberately chosen misconduct reduced an actor's moral responsibility for crime and focused on the reform of the offender rather than the punishment of the offense").

11 See Platt, The Child Savers at 10 (cited in note 5) ("The juvenile court system was part of a general movement directed toward removing adolescents from the criminal law process and creating special programs for delinquent, dependent, and neglected children.").

12 Sarah Freitas, Comment, Extending the Privilege against Self-Incrimination to the Juvenile Waiver Hearing, 62 U Chi L Rev 301, 303 (1995). See also Anne Rankin Mahoney, Juvenile Justice in Context 21 (Northeastern 1987) ("Known as parens patriae ('parent of the nation'), this doctrine was adapted ... to authorize the juvenile court judges to intervene in the lives of children as they saw fit.").

13 Snyder and Sickmund, Juvenile Offenders at 86 (cited in note 1). 
courts, then, was to ensure that minors who did not receive proper guidance would "be protected, nurtured, and treated, rather than held completely responsible and punished for their wrongdoing."

Under such a broad mandate, juvenile courts could intervene at the first sign of potential trouble from a youth, regardless of whether such activity normally would be considered "criminal." 15 The specific details of the crime mattered only to the extent that they might shed light on the type of individual before the court and the prospects for his or her rehabilitation. ${ }^{16}$

2. Limited procedural protections in the juvenile courts.

With such a free-wielding scope of inquiry, a juvenile court proceeding was "anti-legal' in the sense that it encouraged minimum procedural formality and maximum dependency on extra-legal resources." rather than criminal matters, ordinary criminal procedures and due process protections did not apply. ${ }^{18}$ Many states, for instance, simply required a prosecutor to prove his case against a minor by a preponderance of the evidence; statutes did not require courts to provide "defense attorneys, appeals, or even formal procedures." Juries were not used. The judge, any attorneys involved, and the minor "conversed freely about the appropriate resolution" in what was akin to an informal dialogue. ${ }^{20}$ At the same time, this informality ensured that minors would avoid the "stigma of a criminal record," as juvenile hearings were sealed from the press and public."

14 Martin L. Forst and Martha-Elin Blomquist, Cracking Down on Juveniles: The Changing Ideology of Youth Corrections, 5 Notre Dame J L, Ethics, \& Pub Pol 323, 324 (1991). See also Barry C. Feld, Criminalizing Juvenile Justice: Rules of Procedure for the Juvenile Court, 69 Minn L Rev 141, 146-47 (1984) ("[Progressives] focused ... on reforming the offender rather than on punishing the offense. The result was ... open-ended, informal, and highly flexible policies so that the criminal justice professional had the discretion to formulate individualized, case-by-case strategies for rehabilitating the deviant.").

15 See Platt, The Child Savers at 142 (cited in note 5) (noting that juvenile courts could intervene "where no offense had actually been committed but where, for example, a child was posing problems for some person in authority, such as a parent or teacher or social worker").

16 Feld, $78 \mathrm{~J}$ Crim L \& Criminol at 477 (cited in note 7). See also Platt, The Child Savers at 141 (cited in note 5) ("The [juvenile court] judges were authorized to investigate the character and social background of both 'pre-delinquent' and 'delinquent' children. They examined personal motivation as well as criminal intent, seeking to identify the moral reputation of problematic children.").

17 Platt, The Child Savers at 141 (cited in note 5).

18 See Snyder and Sickmund, Juvenile Offenders at 87 (cited in note 1) ("In this benevolent court ... due process protections afforded criminal defendants were deemed unnecessary.").

19 Butts and Harrell, Delinquents or Criminals at 3 (cited in note 2).

20 Freitas, Comment, 62 U Chi L Rev at 304 (cited in note 12).

21 Platt, The Child Savers at 137 (cited in note 5). 
The informal and discretionary nature of juvenile proceedings was especially apparent when a court disposed of a juvenile case. Since reformers perceived juvenile court judges as benevolent guardians, ${ }^{23}$ the courts "enjoyed enormous discretion to make dispositions in the "best interests of the child.", ${ }^{24}$ Concerns about the unlimited nature of such discretion did not worry juvenile court proponents. As one scholar noted, "Early reformers of juvenile court were not unduly concerned about the 'lawless dimension' of discretion. Caught up in the optimism of the era and convinced of the strength of professionalism, they trusted that judges would use it wisely." ${ }^{, 25}$ Consequently, beyond acting in "the best interests of the child," for determining the appropriate treatment for a youth. ${ }^{27}$ The net result of such a framework was that juvenile court dispositions varied tremendously from one case to another. ${ }^{28}$

This discretion extended to the exclusion of the offender from the juvenile justice system altogether. If a juvenile judge determined a "youth was not amenable to ... rehabilitative treatment," the court could waive jurisdiction over the juvenile, at which point the minor would enter the criminal justice system and be tried as an adult. ${ }^{20}$ As with other juvenile court proceedings, such determinations were largely discretionary. ${ }^{30}$ One study, for example, noted: "Transfer decisions were made on a case-by-case basis using a 'best interests of the child and public' standard, and were thus within the realm of individualized justice." ${ }^{31}$ Typically, however, courts waived into adult

22 Since juvenile proceedings are civil and not criminal, a minor is not technically "sentenced" in juvenile court. Rather, the youth's status is adjudicated. If a minor is found to have committed an illegal act, he is "adjudicated" a delinquent and instead of being sentenced receives a disposition plan. See Snyder and Sickmund, Juvenile Offenders at 97-100 (cited in note 1) (outlining the general nature of a juvenile proceeding and distinguishing it from criminal proceedings).

23 See Platt, The Child Savers at 142 (cited in note 5) (noting that the "model" juvenile court judge was seen as a sort of "doctor-counselor rather than [a] lawyer").

24 Feld, $78 \mathrm{~J}$ Crim \& Criminol at 477 (cited in note 7).

25 Mahoney, Juvenile Justice in Context at 23 (cited in note 12).

26 See Snyder and Sickmund, Juvenile Offenders at 87 (cited in note 1).

27 See Feld, $78 \mathrm{~J}$ Crim \& Criminol at 477 (cited in note 7) ("As reflected in juvenile sentencing practices, an extremely wide frame of relevance and an absence of controlling rules or norms characterized this type of decision-making.").

28 Feld, 75 Minn L Rev at 695 (cited in note 5) ("Because a youth's offense was only a symptom of her 'real' needs, sentences were indeterminate, nonproportional, and potentially continued for the duration of minority.").

29 Janet E. Ainsworth, Re-Imagining Childhood and Reconstructing the Legal Order: The Case for Abolishing the Juvenile Court, 69 NCL Rev 1083,1109-11 (1991).

30 See Feld, $78 \mathrm{~J}$ Crim \& Criminol at 478 (cited in note 7) ("From its inception, juvenile court judges also had the discretion to waive serious young offenders from the jurisdiction of the juvenile court to adult criminal courts.").

31 Snyder and Sickmund, Juvenile Offenders at 86 (cited in note 1). 
criminal court older boys arrested for committing more serious crimes.

\section{B. The Federal Response}

1. The Federal Juvenile Delinquency Act of 1938.

By 1925, nearly two-thirds of the states had adopted, in one form or another, a separate juvenile justice system. In the late 1930s, the federal government followed the states' lead and enacted the Federal Juvenile Delinquency Act, which would remain "virtually unchanged" for the next thirty-six years. ${ }^{34}$ The Act, like its state counterparts, provided that a juvenile-defined as anyone under the age of eighteen ${ }^{35}$-charged with violating federal law would be processed as a delinquent rather than tried as an adult criminal. ${ }^{36} \mathrm{~A}$ juvenile found delinquent would either be placed on probation "for a period not exceeding his minority" or committed to the "custody of the Attorney General," who could subsequently place the youth in "any public or private agency or foster home for ... custody, care, subsistence, education, and training." ${ }^{37}$ Similar to the state acts, the FJDA did not provide for jury trials.

Unlike in many states, however, the decision to waive juvenile jurisdiction and try a minor as an adult rested entirely with the Attorney General, rather than the courts. ${ }^{39}$ While some states permitted a prosecutor to waive a juvenile into adult court initially, "most juvenile courts had exclusive original jurisdiction over all youth who were charged with violating criminal laws. Only if the juvenile court waived its jurisdiction in a case could a child be transferred to criminal adult court and tried as an adult.",40

32 See David J. Rothman, Conscience and Convenience: The Asylum and its Alternatives in Progressive America 285 (Harper Collins 1980) (noting that most transferred youths were older males who were charged with violent crimes or large thefts of property).

3318 USC $\$ \S 5031$ et seq (1959).

34 William S. Sessions and Faye M. Bracey, A Synopsis of the Federal Juvenile Delinquency $A c t, 14$ St Mary's L J 509, 509 (1983) (reviewing the basic rights and benefits provided to a juvenile charged with a criminal offense in federal court and discussing in detail the procedures outlined in the FJDA).

3518 USC $\$ 5031$.

3618 USC $\$ 5032$.

3718 USC $\$ 5034$.

3818 USC $\$ 5033$.

3918 USC $\$ 5032$ (stating that a "juvenile ... shall be proceeded against as a juvenile delinquent if he consents to such a procedure, unless the Attorney General, in his discretion, has expressly authorized otherwise"). See also Joseph F. Yeckel, Note, Violent Juvenile Offenders: Rethinking Federal Intervention in Juvenile Justice, 51 Wash U J Urban \& Contemp L 331, 338 (1997) (discussing how the 1938 Act granted the Attorney General "unlimited discretion" in deciding how to prosecute a minor).

40 Snyder and Sickmund, Juvenile Offenders at 86 (cited in note 1). 
2. Deferral to states.

Although the FJDA signaled the federal government's first foray into juvenile justice law, the Act's impact has been relatively minor. In part, this is because the Act has a strong presumption against federal courts handling juvenile cases. Under the FJDA, for example, the federal government may only assert jurisdiction over a juvenile when one of three criteria are met: (1) the state juvenile court lacks or refuses to take jurisdiction over a minor; (2) the state lacks appropriate facilities to handle the juvenile; or (3) the offense is a violent felony or narcotics related crime. In addition, the Attorney General must certify "that there is a substantial Federal interest in the case or the offense" for the matter to proceed. ${ }^{42}$

As a result of this presumption in favor of state courts, most prosecutions of juveniles remain at the state level. ${ }^{43}$ In 1995 , for instance, only 122 juveniles faced delinquency proceedings at the federal level. "By contrast, in 1994, there were over 1.5 million juvenile delinquency cases pending in state juvenile courts.

Despite the small role of the federal government in juvenile cases, the FJDA may become more important as the federal government federalizes more and more crimes. In 1994, for example, portions of the "federal omnibus crime bill encourage[d] or even require [d] federal handling of juveniles when they are charged with gunor gang-related crimes." are "likely [to] result in more juvenile cases being adjudicated in the federal system."

4118 USC $\$ 5032$.

42 Id.

43 See Yeckel, Note, 51 Wash U J Urban \& Contemp L at 338 (cited in note 39) (noting how the "overwhelming majority ... of juvenile offenders are tried in state courts"); Shepherd, 9 Crim Just at 45 (cited in note 1) (noting a "strong presumption" under current law against trying juveniles in federal court). In part, this may stem from the fact that states, unlike the federal government, have facilities especially designed for minors. The federal government closed its last juvenile correction center in the 1980s. Shepherd, 9 Crim Just at 46 . Similarly, the federal government does not have a separate court system devoted exclusively to the handling of juveniles; federal district courts handle proceedings against minors. See 18 USC $\$ 5033$.

44 See John Scalia, Juvenile Delinquents in the Federal Criminal Justice System 3 (Bureau of Justice Statistics 1997).

45 Id.

46 See Shepherd, 9 Crim Just at 47 (cited in note 1) ("Prosecutions of juveniles in federal courts pursuant to the Federal Juvenile Delinquency Act, either as delinquents or as adults after transfer, are likely to increase markedly in the years to come.").

47 Id at 45.

48 Id. For a discussion of the general rise in federal crimes, see Charles D. Bonner, Comment, The Federalization of Crime: Too Much of a Good Thing?, 32 U Rich L Rev 905, 920 (1998) (noting that "between 1980 and 1993, the number of filings of criminal cases [in federal courts] increased by 70 [percent]"). 


\section{EXtension of Due Process into Juventle PRoceEdings}

\section{A. Discontent over the Exercise of Discretion}

During the 1960s, many commentators began to question the unbridled procedural discretion juvenile courts enjoyed. Some critics were motivated by doubts about just how different the sentences handed down by juvenile courts were from those received in criminal courts. As one observer noted, "A concern for procedural protections in juvenile court decision processes grew in part as it became more apparent that in practice the functions of the juvenile justice system closely resembled those of the criminal justice system-punishment, deterrence, and incapacitation of persons who violated the criminal law."

Additionally, and perhaps reflecting the tenor of the times, many charged that limitless discretion "provided a cloak for discrimination rather than individualized justice. ${ }^{30}$ Two researchers, for instance, concluded that being a black male from a lower socio-economic background was more determinative of the manner in which a juvenile court disposed of a case than "the type of past offenses" committed by a minor." Studies also revealed large discrepancies "in the duration and type of intervention or treatment ordered by juvenile authorities." charges of arbitrariness and preferential adjudication. ${ }^{53}$

In response to these criticisms, Presidents Kennedy and Johnson appointed commissions to investigate the handling of juvenile cases at both the state and federal level. A 1967 report by President Johnson's commission declared that the Progressive reforms ushered in sixty years earlier had failed to fulfill their promise. ${ }^{4}$ According to the report, juvenile courts did not "decrease[ ] recidivism" and many juvenile facilities were "corrupt[ed] rather than reform[ed].".s

Indeed, the commission's report indicted the Progressive's entire approach. According to the commission, "[e]xperience[ ] over [the

49 Forst and Blomquist, 5 Notre Dame J L, Ethics, \& Pub Pol at 328 (cited in note 14). See also Mahoney, Juvenile Justice in Context at 24 (cited in note 12) (noting that in the 1960s many critics felt the punishment inflicted on juveniles was "as severe as that meted out to adults, and that children, like adults, should not have their liberty taken away without due process of law").

50 Mahoney, Juvenile Justice in Context at 24 (cited in note 12).

51 Frank R. Scarpitti and Richard M. Stephenson, Juvenile Court Dispositions: Factors in the Decision-making Process, 17 Crim \& Delinquency 142, 150 (1971).

52 Forst and Blomquist, 5 Notre Dame J L, Ethics, \& Pub Pol at 328 (cited in note 14).

53 See Mahoney, Juvenile Justice in Context at 24-25 (cited in note 12) (noting concerns about the impartiality of a system that released an arrested youth "back into the community almost before the arresting officer returned to work while others remained in custody").

54 A Report by the President's Commission on Law Enforcement and Administration of Justice, The Challenge of Crime in a Free Society 84-85 (GPO 1967).

5s Mahoney, Juvenile Justice in Context at 25 (cited in note 12). 
last] half a century with juvenile courts has taught us that these aspirations were greatly over-optimistic and chimerical. The court's wideranging jurisdiction thus has often become an anachronism serving to facilitate gratuitous coercive intrusions into the lives of children and families." At the most basic level, one commentator claimed that the report suggested the "early belief that troubled and troublesome juveniles could be successfully handled in a system based on ... maximum discretion ... failed to yield [satisfactory] results." ", To correct this problem, the commission urged the narrowing of the jurisdiction of juvenile courts and also called for the proceduralization of the juvenile process. ${ }^{\text {s8 }}$

\section{B. Kent and its Progeny}

With its 1966 decision in Kent $v$ United States, ${ }^{59}$ the Supreme Court weighed in on the debate over the appropriateness of "informal" juvenile proceedings and, effectively, "began a procedural revolution" in juvenile justice. ${ }^{60}$ In Kent, a juvenile court acting pursuant to a provision of the Washington, D.C. Code transferred a minor to a federal district court for trial as an adult without holding a hearing or "recit[ing] any reason for the waiver." Kent was subsequently found guilty and sentenced to "a total of 30 to 90 years in prison."."

In light of these facts, the Supreme Court reversed Kent's conviction. Although recognizing that the "Juvenile Court ... [had] considerable latitude within which to determine whether it should retain jurisdiction over a child," the Court found such discretion "[did] not confer upon the Juvenile Court a license for arbitrary procedure." ${ }^{, 63}$ Sweeping aside the Progressives' arguments that informality was necessary to adequately address the individual needs of juveniles, the Court declared that when transferring a minor to adult status "there is no place in our system of law for reaching a result of such tremendous consequences without ceremony - without hearing, without effective assistance of counsel, without a statement of reasons." ${ }^{\text {(4) }}$ Thus, the Court held that any minor facing a waiver was entitled to a hearing, access to court records, and a statement of the grounds for such a transfer. ${ }^{\text {ts }}$

56 The Challenge of Crime at 84-85 (cited in note 54).

57 Mahoney, Juvenile Justice in Context at 30 (cited in note 12).

58 The Challenge of Crime at 85 (cited in note 54).

59383 US 541 (1966).

60 Forst and Blomquist, 5 Notre Dame J L, Ethics, \& Pub Pol at 330 (cited in note 14).

61383 US at 546.

62 Id at 550.

63 Id at 552-53.

64 Id at 554.

65 Id at 557. 
One year later, the Supreme Court extended Kent's due process protection by ruling in In re Gault ${ }^{66}$ that during a juvenile delinquency hearing, a juvenile must be given sufficient notice of the proceedings. In cases that could "result in commitment to an institution in which the juvenile's freedom is curtailed," the Court held juveniles had a right to be represented by an attorney and could have counsel appointed if he or his parents could not afford a lawyer. ${ }^{68}$ The Court also extended the right against self-incrimination to juvenile proceedings, even if they were technically civil dispositions. ${ }^{69}$ Moreover, a minor could no longer be declared a delinquent on hearsay evidence alone; the Court ruled instead that valid, sworn testimony which could be challenged through cross-examination had to be presented in delinquency proceedings. ${ }^{70}$

Following Gault, the Supreme Court continued to impose criminal procedure safeguards on civil juvenile proceedings. In In re Winship, the Court held that in order for a juvenile to be found delinquent, the prosecution must prove its case beyond a reasonable doubt. ${ }^{2}$ Echoing this theme, the Court ruled in Breed $v$ Jones $^{73}$ that the distinctions between delinquency and criminal proceedings were not enough to deny juveniles the Fifth Amendment's protection against double jeopardy. Consequently, a juvenile could not be tried in a criminal setting for conduct previously adjudicated at a delinquency hearing. ${ }^{74}$

The net result of Kent, Gault, Winship, and Breed was to turn the Progressive formula on its head. As Barry Feld, one of the leading authorities on the juvenile justice system, explained: "By emphasizing criminal procedural regularity in the determination of delinquency, the Supreme Court shifted the focus of the juvenile court from the Progressive emphasis on the 'real needs' of the child to proof of the commission of criminal acts, thereby effectively transforming juvenile proceedings into criminal prosecutions." 75 Indeed, the Supreme Court went out of its way to discount the Progressive ideal. In Gault, for instance, the Court emphatically rejected the large amount of discretion

66387 US 1 (1967).

67 Id at 33 .

68 Id at 41.

69 Id at 55.

70 Id at 56-57.

71397 US 358 (1970).

72 Id at 368. In the process, the Supreme Court noted "civil labels and good intentions do not themselves obviate the need for criminal due process safeguards in juvenile courts." Id at 365-66.

73421 US 519 (1975).

74 Id at 541.

75 Feld, 69 Minn L Rev at 161 (cited in note 14). 
associated with juvenile proceedings, warning at one point that "the condition of being a boy does not justify a kangaroo court."

Yet it would be a mistake to suggest the Supreme Court rejected the Progressives' larger goal of keeping minors out of the adult court system. By strengthening procedures in the juvenile process and restricting the ability of a court simply to transfer a juvenile at will to criminal court, the Court implicitly endorsed the idea of treating juveniles differently in the criminal justice system. ${ }^{n}$ In Gault, for instance, the Court, perhaps anticipating the charge of critics that the decision would mean the end of juvenile courts, declared "the commendable principles relating to processing and treatment of juveniles separately from adults are in no way involved or affected by the procedural issues under discussion.",

\section{AMENDMENTS TO THE FEDERAL JUVENILE DELINQUENCY ACT}

In the wake of Kent and its progeny, and the executive reports attacking procedural informalities in juvenile courts, the U.S. Congress amended the Federal Juvenile Delinquency Act" in order to "provide basic procedural rights for juveniles who come under Federal jurisdiction and to bring Federal procedures up to the standards set by various model acts, many state codes and court decisions." with the Kent and Gault decisions, the amendments require that any transfer decision be made on the record, and provide for both the right to a speedy adjudication and the right to counsel.

But the revised Act also goes a step beyond Kent, by altering the criteria for transferring juveniles within the federal court system. It removes the previously unfettered discretion of the Attorney General to transfer a juvenile to adult status and places the responsibility in the hands of federal district courts. ${ }^{2}$ Additionally, the amended Act limits the discretion of district courts to authorize such transfers in the first place. First, it provides that only those juveniles who, after turning fifteen, are charged with committing a crime of violence that would be a felony if committed by an adult, or who are accused of violating certain narcotic laws, may be transferred. Secondly, the Act requires a

\footnotetext{
76 Gault, 387 US at 28.

77 See Kent, 383 US at 556-57 (stressing the seriousness of transferring a minor to adult status).

78387 US at 22.

7918 USC $\$ 5031$ et seq.

80 Juvenile Justice and Delinquency Prevention Act of 1974, S Rep No 93-1011, 93d Cong, 2d Sess 19 (1974).

8118 USC $\$ 5032$.

82 Id (stating that a juvenile may only be transferred to adult status upon the motion of the Attorney General and after a court holds a hearing to consider the transfer motion).

83 Id.
} 
court to determine, after a hearing, that removing the minor from the juvenile justice system "would be in the interest of justice.,"

When considering what would be in the interest of justice, Section 5032 of the statute specifies six factors that courts must consider when deciding whether to waive jurisdiction. ${ }^{85}$ These factors are:

[1] the age and social background of the juvenile; [2] the nature of the alleged offense; [3] the extent and nature of the juvenile's prior delinquency record; [4] the juvenile's present intellectual development and psychological maturity; [5] the nature of past treatment efforts and the juvenile's response to such efforts; and [6] the availability of programs designed to treat the juvenile's behavioral problems.

The government bears the burden of presenting evidence on all six factors. If it fails to address even one of the six elements, the juvenile may not be transferred to adult status.

Courts have held that under the amended FJDA, unlike its Progressive Era counterpart, a juvenile has the right to an immediate, interlocutory appeal of any transfer order. ${ }^{\& s}$ In large measure, this immediate appeal reflects courts' awareness that a transfer carries severe consequences. ${ }^{89}$ As a number of circuits have pointed out, the purpose of the revised FJDA "is to remove juveniles from the ordinary criminal process in order to avoid the stigma of a prior criminal conviction and to encourage treatment and rehabilitation." Courts seem to rec-

84 Id.

85 Id. See also United States $v$ Nelson, 68 F3d 583, 588 (2d Cir 1995) (noting that a "district court is constrained to consider six factors and to make findings in the record regarding each of them").

8618 USC \$ 5032.

87 See United States v Anthony Y., 172 F3d 1249, 1252 (10th Cir 1999) (noting that "the government must present evidence on each factor"), cert denied 120 S Ct 228 (1999); United States $v$ Leon, D.M., 132 F3d 583, 589 (10th Cir 1997) (same). District courts do not have complete discretion in every transfer decision, however. Following the example of the state legislatures, Congress has amended the FJDA so that in certain cases a court must automatically waive the juvenile into criminal court. Under the Act, for example, if a juvenile is over sixteen, was previously found to have committed a felony offense, and is currently charged with a violent offense or certain narcotics offenses, the juvenile is automatically transferred to adult status. See 18 USC $\S$ 5032.

88 Leon, D.M., $132 \mathrm{~F} 3 \mathrm{~d}$ at 587 (citing numerous cases and noting that every circuit that has addressed the question has "concluded that an order transferring a juvenile to adult status is immediately appealable"); United States v Bilbo, 19 F3d 912,914 (5th Cir 1994) (same).

89 See Leon, D.M., 132 F3d at 588 (noting that "a juvenile would lose the legal and practical benefits afforded by the Act if he or she were forced to wait until after a final judgment to appeal an order of transfer to adult status"). See also United States v Gerald N., 900 F2d 189, 190 (9th Cir 1990) ("[W]e conclude - as have our fellow courts of appeals that have considered the issue-that the legal and practical value of the right to be tried as a juvenile would be destroyed without the concomitant right of immediate appeal.").

90 United States v Brian N., 900 F2d 218, 220 (10th Cir 1990). See S Rep No 93-1011 at 22 (cited in note 80 ) (declaring that the Act's goal is "to assist youth in becoming productive mem- 
ognize that by removing the minor from the juvenile justice process, the juvenile faces publicity, the possibility of incarceration amongst adults, stiffer penalties, and a felony record. ${ }^{\text {91 }}$ As one commentator observed, "criminal court transfer offers a drastic and permanent solution for an offender thought to be beyond redemption. It is the court's way of saying, "there are no more second chances for you."," Consequently, a transfer is properly granted only when a court, after considering the six statutory factors, "determines that the risk of harm to society posed by affording the defendant more lenient treatment within the juvenile justice system outweighs the defendant's chance for rehabilitation."

Despite these statutory guidelines, courts continue to enjoy considerable latitude in deciding whether a transfer should go forward. As a number of circuits have noted, "the district court need not find that each factor weighs in favor of transfer in order to grant the government's motion." Nor are courts required to give each factor equal weight in reaching a transfer decision. In fact, a district court need not decide whether a particular factor weighs in favor or against transferring the minor. "Essentially, "the district court must balance the

bers of our society ... by ... channel[ing] juveniles, for whom the criminal justice system is inappropriate, away from and out of the system into human problem-solving agencies and professions").

91 See Gerald N., $900 \mathrm{~F} 2 \mathrm{~d}$ at 190 . See also Shepherd, 9 Crim Just at 47 (cited in note 1) (noting "[a] juvenile's conviction as an adult subsequent to certification and transfer carries with it all the consequences that would befall an adult. In fact, 'youth' is not even a specific factor for a downward adjustment in a federal sentence under the guidelines.").

92 Butts and Harrell, Delinquents or Criminals at 7 (cited in note 2). See also Thomas F. Geraghty and Will Rhee, Learning from Tragedy: Representing Children in Discretionary Transfer Hearings, 33 Wake Forest $\mathrm{L} \operatorname{Rev} 595,599$ (1998) ("Every transfer is a tragedy. It is a tragedy for the children-many of whom have already experienced too much tragedy in their young lives and now must face the harsher penalties of the criminal court.").

93 United States v One Juvenile Male, 40 F3d 841, 844 (6th Cir 1994).

94 Anthony $Y ., 172$ F3d at 1252.

95 See United States $v$ Juvenile Male \#1, 47 F3d 68, 71 (2d Cir 1995) (noting that a district court "is not required to afford equal weight to each factor, but instead may balance them as it deems appropriate"). See also United States $v$ Wilson, 149 F3d 610, 614 (7th Cir 1998) (holding that district courts have the "discretion to give more weight to some factors than to others"); United States $v$ Juvenile JG, 139 F3d 584, 586-87 (8th Cir 1998) (concluding that the trial court may use its discretion in assigning different weights to each factor); United States $v$ Wellington, 102 F3d 499, 506 (11th Cir 1996) (noting that a district court, after considering each of the six factors, may weigh them "as it deems appropriate"); United States v A.R., 38 F3d 699, 705 (3d Cir 1994) (noting a court may "give more weight to [one] factor than to others"); United States $v$ Doe, 871 F2d 1248, 1254-55 (5th Cir 1989) ("A court is certainly not required to weigh all statutory factors equally.").

96 Anthony Y.,172 F3d at 1252, quoting Juvenile Male \#1,47 F3d at 71 ("[A district court] is not required to state whether each specific factor favors or disfavors transfer"). See also Wellington, 102 F3d at 505 ("Section 5032 simply requires a finding on the record as to each factor, but does not require that ... each factor [be] weighed for or against the transfer."); United States $v$ Three Male Juveniles, 49 F3d 1058, 1061 (5th Cir 1995) (concluding that a district court need not state whether a factor weighs for or against transfer). 
evidence before it, weighing each factor as it sees fit." ${ }^{\text {,97 }}$ As a result of this deference, appellate courts review the transfer decision only for an "abuse of discretion" or a "clearly erroneous" conclusion."

\section{CONFLICTS OVER THE DEFINITION OF PRIOR JUVENILE DELINQUENCY RECORD}

Because of the limited but still discretionary power to transfer minors under the FJDA, the definition of each statutory factor is important. Since district courts can give one factor (for example, the nature of the alleged offense) more weight than another (for example, social background), a juvenile could conceivably be transferred mainly due to one statutory element. ${ }^{99}$ This concern becomes even greater when it is noted that "[i]n many, if not most, juvenile cases handled in district court pursuant to the Federal Juvenile Delinquency Act, certification is followed by a motion for transfer to adult criminal status and trial as an adult."100

Within the last decade, this concern has manifested itself in courts disagreeing over the interpretation of one of the six factors: prior juvenile delinquency record. One circuit has suggested that only prior, adjudicated conduct may be considered under this factor. ${ }^{101}$ Others have held that although certain unadjudicated and uncharged conduct may not be considered under the prior record factor, it may be evaluated under a more elastic factor, such as social background. ${ }^{102}$ Still another circuit has read the term as including prior, unadjudicated arrests. ${ }^{103}$

97 Anthony $Y, 172$ F3d at 1252.

98 See Nelson, $68 \mathrm{F3d}$ at 588 ("The decision of the district court [to transfer] is a discretionary one and will not be disturbed except upon our finding of an abuse of discretion. A district court is said to have abused its discretion when it fails to make the required factual findings or where the findings it does make are clearly erroneous.") (citation omitted); United States v Alexander, 695 F2d 398, 400 (9th Cir 1982) ("[T] he decision to transfer a juvenile to adult status is within the sound discretion of the district judge.").

99 See, for example, United States $v$ Wilson, 149 F3d 610, 613 (7th Cir 1998) (upholding transfer where only one factor weighed in favor).

100 Shepherd, 9 Crim Just at 46 (cited in note 1). But see Scalia, Juvenile Delinquents at 2 (cited in note 44) ("While the Department of Justice does not systematically collect information describing Federal juvenile transfers, it estimates that during the 12 months ending September $30,1994,65$ persons accused of delinquency were referred to the Attorney General for transfer to adult status.").

101 See In re Sealed Case, 893 F2d 363, 369 n 12 (DC Cir 1990) (arguing "Congress could not have contemplated the hearing to focus on a plethora of uncharged and unproven offenses").

102 See, for example, United States v Juvenile LWO, 160 F3d 1179, 1183 (8th Cir 1998) (concluding the social background and intellectual immaturity factors are broad enough to look at "almost any action, criminal or otherwise, the juvenile has taken").

103 Wilson, 149 F3d at 613 (concluding prior record includes prior arrest). 


\section{A. Full Exclusion of Prior Unadjudicated Conduct}

In In re Sealed Case, ${ }^{104}$ the D.C. Circuit became the first circuit to express concerns about the inclusion of unadjudicated, prior conduct in transfer hearings. In re Sealed Case involved a juvenile who was arrested and charged with three counts of cocaine distribution. The government moved, pursuant to Section 5032, to transfer the minor to adult status "so that it could prosecute him criminally." In making its motion, the government presented evidence under the "nature of the offense" factor that the juvenile had been involved in a larger drug conspiracy, even though the minor had not been charged with that offense. ${ }^{\text {tof }}$ After hearing the evidence, the district transferred the minor to adult status. ${ }^{107}$

The D.C. Circuit, however, held such evidence was inappropriate for consideration and reversed the transfer. ${ }^{108}$ The court concluded that considering uncharged conduct within the "nature of the alleged offense" factor would violate the juvenile's due process rights. ${ }^{109}$ Under the FJDA, the court explained, a judge "is entitled to assume that the juvenile committed the offense charged for the purpose of the transfer hearing." ${ }^{\text {"10 }}$ Such a presumption does not violate due process, the court reasoned, because "the trial itself functions as a corrective for any reliance on inaccurate allegations made at the transfer stage." "111

However, because evidence pertaining to the other five categories may not be relevant at a subsequent trial, the D.C. Circuit held that the trial judge may not make assumptions about the remaining factors, and a juvenile must be able to challenge the government's position regarding those factors at the transfer hearing. ${ }^{112}$ If the "nature of the alleged offense" category were extended to include uncharged criminal offenses, the juvenile court would be able to make unchallenged assumptions about certain activity that ultimately "[would] not be corrected at trial." "13 Thus, allowing "the transfer hearing judge to presume those [uncharged] allegations true ... would violate a juvenile's due process rights.",

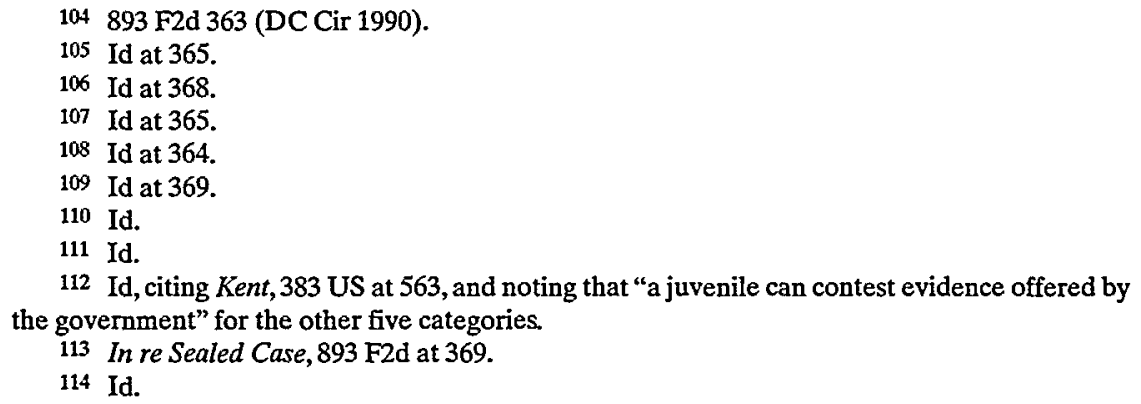


Up until this point, the court's argument only seemed to extend to due process considerations and the narrow concerns over the "nature of the alleged offense" factor. The definition of prior conduct did not seem to be implicated. Yet the court proceeded to claim that the six transfer factors were intended to limit "the kind of information that comes before a judge at a transfer hearing." ciple, the court suggested that regardless of due process concerns, considering evidence of unadjudicated and uncharged conduct would be inappropriate. "[S]ince ... the purpose of the Act is rehabilitation and not punishment," the court argued that "Congress could not have contemplated the hearing to focus on a plethora of uncharged and unproven offenses." "116

By implication, therefore, the D.C. Circuit's dicta suggested that the scope of "prior record" did not include uncharged or unadjudicated conduct. If such conduct could not be reviewed under either the prior record or nature of offense factor, the court implied that it could not be reviewed at all. The court suggested that only the nature of the offense and prior delinquency record factors specifically allow for the contemplation of violations of the law, while the remaining factors (that is, social background, intellectual maturity, and past treatment efforts) require "a transfer judge to make findings ... entirely unrelated to the juvenile's alleged violations of the law.",

B. Excluded under Prior Record but Included under Another Factor

The D.C. Circuit's suggestion that a court could only analyze actual adjudications under the "prior record" prong was later endorsed by the Eighth Circuit. Yet at the same time, that court, in contrast to In re Sealed Case, liberally interpreted other factors so that a transferring court could consider unadjudicated prior criminal conduct.

In United States $v$ Juvenile $L W O,{ }^{118}$ a Native American youth, LWO, broke into a home, stole a rifle, and twice shot one of the homeowners who returned and discovered the break-in while LWO was still on the property. ${ }^{119}$ LWO was subsequently arrested and charged with "assault with a dangerous weapon, assault resulting in serious bodily injury, first degree burglary, and use of a firearm in the commission of a felony." ${ }^{\text {,20 }}$ Not surprisingly, the government moved to transfer LWO to adult status under Section 5032.

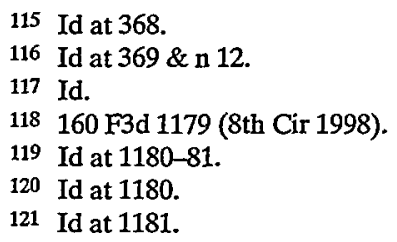


During the subsequent transfer hearing, the government introduced evidence of LWO's numerous run-ins with the tribal court system, including an incident in which LWO allegedly "beat his girlfriend and kicked and struck tribal police officers." vealed that LWO was charged with "offenses of intoxication, profane language, assault, and resisting lawful arrest" as a result of this altercation, but that "no disposition of these offenses" had occurred " because a hearing "was pending." 124

In addition to these charges, a government witness testified that LWO had been "one of four people involved" in an assault on a tribal resident. ${ }^{125}$ Although the tribal court records indicated LWO had been arrested for public intoxication, "no reference to any charges or offenses arising out [of] the alleged assault" existed. ${ }^{126}$ Thus, LWO forced the court to answer two key questions. First, whether "a district court may consider evidence of an uncharged assault in determining whether a transfer would be in the interest of justice," and, second, "whether a district court may consider evidence of an assault for which there has been a charge but no conviction.",127

The Eighth Circuit began its analysis by pointing out that " $[t]$ he plain language of the statute does not explicitly mention offenses for which there has been no charge or a charge but no conviction." "Citing In re Sealed Case, the court concluded that unadjudicated offenses could not be considered under the "nature of the offense" category." The court then made explicit what was implicit in In re Sealed Case's analysis. According to the court:

[J]ust as the D.C. Circuit believed that the plain language of the term "the nature of the alleged offense" could not plausibly be interpreted to encompass evidence of unalleged offenses ... we believe that the plain language of the term "the juvenile's prior delinquency record" cannot plausibly be interpreted to encompass . .. evidence of conduct which has not been adjudicated or admitted to be delinquent or criminal. ${ }^{130}$

122 Id.

123 Id.

124 Id at 1182. LWO's court record also included adjudicated offenses involving "malicious mischief," "fighting," and "spouse abuse." Id at 1181.

125 Id.

126 Id.

127 Id at 1182 .

128 Id.

129 Id at 1183, quoting In re Sealed Case, 893 F2d at 365 ("We agree with the D.C. Circuit's reasoning and its conclusion that Section 5032 'does not authorize a judge to consider evidence of other crimes in assessing "the nature of the alleged offense."”).

$130160 \mathrm{~F} 3 \mathrm{~d}$ at 1183. 
Consequently, the court concluded, "the plain language of the term 'the juvenile's prior delinquency record' would not encompass evidence of incidents or behavior, which could be of a delinquent or criminal nature, for which there has been no charge or a charge but no conviction." ${ }^{131}$

However, even though the Eighth Circuit agreed with the D.C. Circuit's narrow reading of Section 5032 when interpreting the term "prior record," it found room under the statute to include the alleged offenses. The court explicitly disavowed In re Sealed Case's interpretation that the Section 5032 factors relating to "age and social background ... present intellectual development and psychological maturity ... [and] the nature of past treatment efforts [are] ... entirely unrelated to the juvenile's alleged violations of the law.",132 Instead, the court concluded, "the plain language of those terms is broad enough to authorize the admission of evidence regarding almost any action, criminal or otherwise."133 As a result, the court reasoned that district courts had the "sound discretion ... to admit evidence of other incidents ... alleged to be criminal or delinquent" if they were somehow relevant to the remaining four factors. ${ }^{13}$

Perhaps recognizing the potential breadth of such an interpretation, the court admonished district courts that "[w]hen dealing with evidence of other incidents, behavior, and resulting charges, if any, [they] ... must consider the nature of the particular factor and precisely how the alleged incidents, behavior, charges, and surrounding circumstances are relevant to that factor., ${ }^{133}$

Although declining to decide whether unadjudicated and uncharged conduct could be considered under the "prior conduct" prong of Section 5032, the Tenth Circuit recently joined the Eighth Circuit by holding, in United States $v$ Anthony Y., ${ }^{136}$ that even if prior arrests could not be considered part of a juvenile's prior delinquency record, they could be weighed under one of the four remaining transfer factors, such as social background. ${ }^{13}$

131 Id. It should be noted that by making this ruling, the Eighth Circuit implicitly overruled its precedent which had, without explanation, held that unadjudicated arrests could be considered under the prior record prong. See United States $v$ Parker, 956 F2d 169, 172 (8th Cir 1992) (noting that "although Parker had no official delinquency record, he had been arrested for burglary of a church and for a weapons offense").

132 LWO, $160 \mathrm{~F} 3 \mathrm{~d}$ at 1183 .

133 Id (emphasis added).

134 Id.

135 Id at 1183-84.

136172 F3d 1249 (10th Cir 1999).

137 Id at 1253-54 (concluding that a juvenile's alleged assault on a school counselor might be considered as evidence of the juvenile's response to past treatment efforts and that conduct while in custody "relates to his present intellectual development"). The Tenth Circuit explicitly noted that "[e]ven if we limited Anthony Y.'s prior delinquency to the three adjudicated offenses, 


\section{Inclusion of Unadjudicated Arrests in the Definition of Prior Conduct}

Prior to the Eight Circuit's ruling in $L W O$, the Seventh Circuit heard oral arguments in a case that also raised questions about the definition of a prior delinquency record. In United States $v$ Wilson, ${ }^{1,8}$ a sixteen-year-old minor was charged with "three counts of distributing cocaine and one count of distributing crack." ${ }^{139}$ During Wilson's transfer hearing, the district court "considered ... a number of arrests that did not result in convictions. "140 Citing In re Sealed Case, Wilson asserted the government could only consider prior convictions when looking at his "juvenile record." "141

The Seventh Circuit rejected this argument. Noting the "paucity of case law interpreting this part of the transfer statute," and without defining what constituted a juvenile record, the court concluded: "Congress could have limited the inquiry to the juvenile's prior convictions, but it did not.", Without offering reasons for its interpretation, the court, in contrast to LWO and In re Sealed Case, then defined "delinquency record" as including "arrests as well as convictions.,"

That stated, the opinion proceeded to limit the district court's examination of the reasons behind the arrest, holding "the government should not be allowed to hold mini-trials, attempting to prove the underlying conduct in those instances where an arrest did not result in a conviction. Such evidence is outside the juvenile's record and thus is not within the limits contemplated by the statute.", ${ }^{\text {lit }}$ The court, however, did not explain what defines the limits of the statute or why an unadjudicated arrest is within those bounds. ${ }^{145}$

Pragmatically, the Wilson rule appears to allow a court to weigh the fact that an arrest occurred and consider the reason for the arrest without having to determine whether such conduct actually occurred. Essentially, the holding suggests a court would note that " $X$ " was arrested for "Y," though ultimately not charged or convicted. The net ef-

\footnotetext{
the additional conduct considered by the district court was relevant to several of the other statutory factors, like 'the age and social background of the juvenile,' 'the juvenile's present intellectual development and psychological maturity,' or 'the nature of past treatment efforts and the juvenile's response to such efforts." Id at 1253.

138149 F3d 610 (7th Cir 1998).

139 Id at 611.

140 Id at 613.

141 Id.

142 Id.

143 Id.

144 Id.

145 The court seemed especially concerned that a tremendous amount of evidence regarding unadjudicated conduct "would greatly burden the parties ... with no discernable benefit." Id. Yet, as with the determination that arrests are not beyond the scope of permissible considerations, the court did not articulate why no discernable benefit would result.
} 
fect of considering such arrests seems to "strengthen[ ] the Government's case for transfer."

In sum, decisions from several circuits point in different directions. The D.C. Circuit has suggested that unadjudicated and uncharged conduct may not be considered under the FJDA. In contrast, the Eighth Circuit has indicated that while such conduct may not be examined as part of a juvenile's prior delinquency record, it may be considered under other statutory factors. The Tenth Circuit, declining to consider the definition of prior delinquency record, has also allowed unadjudicated and uncharged conduct to be reviewed under other transfer factors. Meanwhile, the Seventh Circuit, addressing only the narrower question of unadjudicated arrests, has bucked the trend to hold that arrests are part of a juvenile's prior record. As the Sixth Circuit recently noted, "[t]he scope of $\S 5032$ 's reference to the 'juvenile record' is indeed unclear.",147

\section{TOWARD A SOLUTION}

Given the lack of agreement among the circuits, this Part attempts to identify the appropriate interpretation of "prior delinquency record." To do so, this Part first considers whether it is appropriate to read "prior record" as incorporating unadjudicated arrests, as the Seventh Circuit has, or whether, as the Eighth Circuit has argued, such arrests are outside the category. This discussion then looks at whether the Eighth Circuit's approach of permitting behavior excluded from the prior record factor to be reviewed under other statutory factors is consistent with the text and goals of the statute. Ultimately, this Part concludes that a construction of "prior record" that permits the consideration of prior arrests but that prohibits the consideration of uncharged criminal conduct is most appropriate.

146 United States $v$ Jarrett, 133 F3d 519, 537 (7th Cir 1998). Jarrett, ironically, involved a convicted juvenile who claimed the government's failure to introduce his prior, unadjudicated arrests violated certain provisions of Section 5032 that require the government to submit a minor's juvenile records to the court before the transfer hearing. Id. The Jarrett court held that because the other records alluded to by Jarrett did not lead "to a conviction or punishment" they did not have to be reviewed by the district court. Id. Jarrett and Wilson, taken together, create a puzzling tension: unadjudicated arrests are not part of a juvenile's record for purposes of providing the court with the record, but they are part of the juvenile's records for purposes of transferring the juvenile to criminal court.

147 United States v A.R., 203 F3d 955, 961 (6th Cir 2000). 
A. Unadjudicated Prior Arrests

1. The case against consideration.

A compelling argument can be made that a court should not construe "prior delinquency record" as including prior arrests that did not result in convictions. First, the statute is very clear in stating that the juvenile's "prior delinquency record" shall be considered, ${ }^{148}$ not prior criminal conduct or prior illicit behavior. Unlike some state statutes that explicitly define prior juvenile records as including prior arrests, ${ }^{149}$ the FJDA does not overtly incorporate prior arrests into the prior record prong. ${ }^{1.5}$ Moreover, Section 5031 of the FJDA defines juvenile delinquency as being "the violation of a law of the United States committed by a person prior to his eighteenth birthday which would have been a crime if committed by an adult." ${ }^{, 15}$ Thus, by inserting this definition into the "prior delinquency record" language, one could claim that only actual violations of the law may be considered. Consequently, without an actual adjudication or conviction, it is inappropriate, one could claim, to assume an arrest reflects a "prior law violation."

2. The FJDA supports including prior arrests.

Admittedly, the Seventh Circuit's reasoning in Wilson for including "prior arrests" as part of one's prior record is underdeveloped. ${ }^{152}$ In the end, however, the Seventh Circuit's inclusion of prior arrests within the prior delinquency record factor seems appropriate.

Although the FJDA does not expressly define the meaning of a prior delinquency record, it does not follow that prior arrest records are excluded from consideration. Other courts have noted, for example, that "[i]n general, when ... [courts] speak of a witness's or defendant's 'record,' [they] refer to a set of facts about that person, consisting of each previous arrest, whether the arrest led to conviction, and if so, the sentence imposed and served. Those facts are usually transcribed into a single document, which is also called the defendant's 'record' (or sometimes, 'rap sheet')." ${ }^{\text {,153 }}$ Nothing in the FJDA suggests

14818 USC $\$ 5032$.

149 See, for example, Mich Ct Rules, $\$ 5.950$ (West 1999) (defining prior delinquency record for purposes of transfer as "including, but not limited to, any record of detention, any police record, any school record, or any other evidence indicating prior delinquent behavior").

15018 USC $\$ 5032$.

15118 USC $\$ 5031$.

152 See text accompanying notes $143-45$.

153 Camitsch v Risley, 705 F2d 351,353 (9th Cir 1983). See also Aguillard v McGowen, 2000 US App LEXIS 3884, *10 (5th Cir) (describing defendant's criminal record as including "arrests for driving while intoxicated, driving with a suspended license, resisting arrest, public drunken- 
that when drafting the 1974 amendments Congress intended to depart from this general definition of prior record. And, indeed, a number of district courts seem almost reflexively to consider prior, unadjudicated arrests as being a part of a juvenile's prior delinquency record. ${ }^{1.4}$ Some state statutes that do not explicitly include arrests in their definition of prior records have also been construed as including prior arrests. ${ }^{155}$ In light of the FDJA's silence on the proper definition of record, it seems appropriate to define the term as corresponding with these general rules.

ness, and a conviction for assault and battery"); United States v Merrival, 176 F3d 1079, 1081 (8th Cir 1999) (noting that during a sentencing hearing a defendant's prior criminal record includes tribal arrests); United States $v$ Neff, 1998 US App LEXIS 12483, *4 (2d Cir) (describing a prior criminal record as including both convictions and "other arrests"); United States v McClinton, 982 F2d 278, 283 (8th Cir 1992) (noting that defendant's criminal record included "five additional prior arrests that did not result in prosecution"); Osaghe v INS, 942 F2d 1160, 1163 (7th Cir 1991) (describing arrests as part of a criminal record); United States $v$ Sanchez, 30 F Supp 2d 595, 596 (E D NY 1998) (describing how a police check on a license plate revealed a criminal record that "includ[ed] arrests for drug related offenses"); Fullard $v$ City of Philadelphia, 1996 US Dist LEXIS 5321, *3-4 (E D Pa) (describing a prior record as including "prior arrests for robbery, burglary, theft, receiving stolen property, unauthorized use of an automobile, making terroristic threats, simple assault, and drug-related offenses"); United States v Minor, 1991 US Dist LEXIS 15528 , *3 (D DC) (describing a defendant's prior record as including "one conviction for possession of marijuana, one conviction relating to possession of a firearm, and nine prior arrests, four of which were for drug offenses"). For an example of what Camitsch calls a rap sheet containing both arrests and convictions, see United States v Denson, 668 F Supp 1531, 1535-39 (S D Fla 1987) (attaching a rap sheet to opinion). But compare Randie P. Ullman, Note, Federal Juvenile Waiver Practices: $A$ Contextual Approach to the Consideration of Prior Delinquency Records, 68 Fordham L Rev 1329, 1355 (2000) ("In general criminal law vernacular, 'criminal records' refer to prior offenses that resulted in convictions.").

154 See, for example, United States v John Doe \#1, 1999 US Dist LEXIS 12992, *14 (S D NY) (noting how the Second Circuit "has given its implicit support to the notion that a juvenile's previous arrests may be relevant to the "prior juvenile record' factor"); United States $v$ One Juvenile Male, 51 F Supp 2d 1094, 1098 (D Or 1999) (discussing numerous juvenile arrests that did not result in charges or in which charges were later dismissed); United States v Dion L., 19 F Supp 2d 1224,1226 (D NM 1998) (considering prior arrests for vandalism and marijuana possession though ultimately concluding they were too minor to favor transfer); United States $v$ M.H., $901 \mathrm{~F}$ Supp 1211, 1215 (ED Tex 1995) (including prior arrests under prior record).

155 See, for instance, State v Janelle L.I., 1999 Wisc App LEXIS 740, *4 (noting that juvenile's prior record included "sixty police contacts").

156 Such an interpretation is also in accordance with canons of statutory construction, including the principle that legislation using a widely accepted judicial term should not be construed as changing the term's accepted meaning, unless Congress expressly states otherwise. See Commissioner v Keystone Consolidated Industries, Inc, 508 US 152, 158-59 (1993) (concluding that because the "phrase 'sale or exchange' had acquired a settled judicial and administrative interpretation over the course of a half century before when" Congress enacted particular legislation using those terms, Congress "presumptively was aware" of the language's meaning); Hardy Salt Co v Sanders Brine Shrimp Co, 501 F2d 1156, 1168 (10th Cir 1974) ("When Congress uses words in a statute without defining them, and those words have a judicially settled meaning, it is presumed that Congress intended them to have that meaning within the statute."). In recent years this doctrine has been invoked by Justice Stevens to contend that courts should be reluctant "to give sweeping effect and broad literal application to statutory language where the language operates to alter a status quo of long-standing consensus or would tend to make for an absurd or bizarre result." Jeffery W. Stempel, Reason and Pollution: Correctly Construing the "Abso- 
Even if prior arrest records may be considered as part of a juvenile's prior delinquency record, the Seventh Circuit's conclusion "that the government should not be allowed to hold mini-trials, attempting to prove the underlying conduct in those instances where an arrest did not result in a conviction"15 needs refinement. The Seventh Circuit never fully articulated its reason for prohibiting mini-trials other than to suggest they would waste resources and to assert they are beyond the scope of the FJDA. ${ }^{158}$ Ostensibly, this holding suggests that the government cannot engage in a fishing expedition to prove the juvenile's "bad character."

This conclusion, however, must not be interpreted to mean that the juvenile may not challenge the probative value of a previous arrest. An arrest, in and of itself, does not prove a violation of the law. ${ }^{159}$ As the Supreme Court explained years ago, "[t]he mere fact that a man has been arrested has very little, if any, probative value in showing that he has engaged in any misconduct. An arrest shows nothing more than that someone probably suspected the person apprehended of an offense." "The Seventh Circuit recently echoed this theme, noting that an arrest record "'by itself' cannot be 'reliable information' that defendant engaged in prior criminal conduct." 161

The use of arrest records, more generally, raises reliability concerns. ${ }^{1 \times 2}$ As the Seventh Circuit previously held, when sentencing an adult (who has been found guilty of a crime), "there is some question whether ... [a court] could even consider juvenile conduct not leading to conviction to be 'reliable information' due to the 'differential availability of records' in each state concerning juvenile arrests."

lute" Exclusions in Context and in Accord with Its Purpose and Party Expectations, 34 Tort \& Ins L J 1, 36 n 151. In such circumstances, "the fact that the dog did not bark"-that Congress did not specifically announce or indicate a change in policy-"can itself be significant." Griffin v Oceanic Contractors, Inc, 458 US 564, 589 (1982) (Stevens dissenting). See also Harrison v PPG Industries, Inc, 446 US 578, 602 (1980) (Rehnquist dissenting) (recognizing the "dog did not bark" approach as a legitimate means of statutory interpretation).

157 Wilson, 149 F3d at 613.

158 Id. Read in its entirety, the reason for this prohibition may stem from concerns over the due process issues articulated in In re Sealed Case. The section of Wilson immediately proceeding the prior record analysis dealt with a due process challenge. See id at 612-13. The court, however, never made this link, and this Comment is reluctant to impute such a motive.

159 See United States v Gammon, 961 F2d 103, 108 (7th Cir 1992) ("[U]se of prior juvenile arrests is also troubling because [the district court] relied solely on the information contained in the presentence report, which merely stated, '[the defendant] had the following juvenile arrests ....'This information was not sufficient for the district court to rely on because it is analogous to an arrest record.").

160 Schware v Board of Bar Examiners, 353 US 232, 241 (1957).

161 Gammon, 961 F2d at 108, quoting United States v Terry, 930 F2d 542, 545-46 (7th Cir 1991).

162 See Snyder and Sickmund, Juvenile Offenders at 143 (cited in note 1) ("Half of the prosecutor officers using juvenile history records criticized their lack of completeness.").

163 Gammon, 961 F2d at 108. 
More specifically, the use of arrest records without the opportunity for challenge by the minor could disproportionately and inappropriately characterize minorities as youthful offenders. As one commentator observed, "although African-American youth age ten to seventeen constitute 15 percent of the U.S. population, they account for 26 percent of juvenile arrests." ${ }^{164}$ Recently, in fact, some have criticized the willingness of police officers to "use race as a proxy for an increased risk of criminality." "As a result of this "proxy," some have concluded African-American males are "vastly overrepresented" in the criminal justice system. ${ }^{160}$ As one commentator explained, possible inequalities in the justice system "reach down to the first level of the criminal justice process, the points at which police decide who they will investigate, approach, stop, frisk, and ultimately arrest." ${ }^{367}$ Given both the questionable reliability of police records and the possible disparate impact their use may have on minorities, it is only appropriate that juveniles be given the opportunity to challenge the probative value of such records during transfer hearings.

In addition, to deny a juvenile the right to challenge the validity of such arrest records would seem to run afoul of the Supreme Court's holding in Kent that material used in a transfer hearing be "susceptible to challenge or impeachment."168 If a juvenile is not allowed to question the validity of a prior arrest, then the transferring court would be able to assume the truth of the underlying conduct without the possibility of later correction at trial. This is the very sort of faulty due process rejected in In re Sealed Case. ${ }^{169}$ While permitting the juvenile

164 See Finley and Schindler, 63 Fed Prob at 11 (cited in note 1). See also Snyder and Sickmund, Juvenile Offenders at 193 (cited in note 1) (noting "existing research suggests that race/ethnicity does make a difference in juvenile justice decisions in some jurisdictions at least some of the time"); Feld, 84 Minn L Rev at 362 (cited in note 1) (noting that "since the mid1960 s, police have arrested black juveniles under eighteen years of age for all violent offenses ... at a rate about five times greater than that of white youth").

165 Randall Kennedy, Race, Crime, and the Law 137 (Pantheon 1997). See also David A. Harris, Factors for Reasonable Suspicion: When Black and Poor Means Stopped and Frisked, 69 Ind L J 659, 688 (1994) (concluding more stringent probable cause standards must be applied to avoid the over-targeting of minorities for police stops in high crime areas); Tracey Maclin,"Black and Blue Encounters"-Some Preliminary Thoughts about Fourth Amendment Seizures: Should Race Matter?, 26 Valp U L Rev 243, 260 (1991) ("Black men are considered suspicious and targeted for questioning not because of any objective or empirical evidence that they are engaged in criminality, but because of police bias and societal indifference to the plight of black males who are on the receiving-end of aggressive police tactics.").

166 Harris, 69 Ind L J at 679 (cited in note 165 ).

167 Id.

168 Kent, 383 US at 563 . The Supreme Court made this statement in reference to staff reports that normally would not be available for review by an attorney.

169 See In re Sealed Case, 893 F2d at 369 (noting how "[a]llegations of other uncharged acts . .. will not be correct[ed] at trial" if brought in under the nature of the alleged offense prong); $L W O, 160$ F3d at 1183 (agreeing that allegations of uncharged crime cannot be corrected at the trial stage). 
to challenge the probative value of arrest records may result in the "mini-trials" condemned by the Wilson court, the juvenile's due process rights require such a holding.

Moreover, to deny the juvenile the right to challenge the validity of the underlying facts of an arrest is at odds with the Seventh Circuit's holdings in analogous adult contexts. The court has suggested, for instance, that unadjudicated juvenile arrests should only be used to increase an adult sentence where the reports are reliable (such as when a detailed police report is made) and where the defendant is able to challenge the "underlying facts" of the arrest. ${ }^{170}$ If an adult who has already been tried and convicted of a crime may challenge the probative value of a juvenile arrest during sentencing, it seems odd to prohibit a juvenile from doing the same when he has yet to be even tried let alone convicted.

Consequently, in light of precedent and the text of the FJDA, evidence of prior arrests should be admitted under the prior delinquency record prong of the FJDA. However, that admission must be with the express caveat that the juvenile should be able to challenge the reliability and probative value of such arrests during the transfer hearing.

\section{B. Uncharged Criminal Conduct}

Whether a court may examine uncharged criminal conduct ${ }^{17}$ is a far more elusive question. For example, in $L W O$, the Eighth Circuit not only considered allegedly criminal conduct on which a hearing was pending (that is, a prior arrest), but it also allowed the district court to consider an assault for which LWO had been neither charged nor arrested (that is, uncharged conduct). ${ }^{12}$ That court, however, concluded such conduct should not be seen as part of a juvenile's prior record, but could be reviewed under other statutory factors. Thus, one must consider whether such behavior should be reviewed under the prior record factors, other Section 5032 factors, or not at all.

1. Part of a prior juvenile record.

No circuit has held explicitly that courts may consider criminallike conduct for which an individual has never been arrested or

170 See United States $v$ Terry, 930 F2d 542,546 (7th Cir 1991) (contending that the defendant could object to the underlying facts surrounding juvenile arrests during an adult sentencing phase, but failed to do so).

171 Certainly, a person might be arrested but subsequently not charged for a crime. However, in this context, I use uncharged criminal conduct to mean alleged criminal conduct for which a juvenile was never arrested.

172 LWO, 160 F3d at 1182-84. 
charged as part of a prior delinquency record. ${ }^{173}$ Several district courts, however, have considered uncharged and even non-criminal conduct when looking at a juvenile's prior delinquency record. ${ }^{174}$ Such an interpretation goes beyond the scope of traditional definitions of what is commonly called a criminal record. ${ }^{175}$ Indeed, if a court could examine an array of uncharged-or unchargeable-conduct under the prior record factor, it effectively creates a "prior conduct" prong. Such an approach, it was recently noted, risks allowing judges to "mak[e]-up the content of the [transfer] criteria ... and allows judges to skew a transfer decision in the direction they personally favor." ${ }^{176}$ This type of open-ended approach would invite the unfettered examinations Section 5032 was designed to prevent. Consequently, since circuits expressly considering the meaning of prior delinquency record have not permitted such an interpretation, and since such a reading appears to be at odds with the test of Section 5032, it seems inappropriate for a court to include under the prior record factor conduct for which a juvenile has never been charged or arrested. ${ }^{17}$

2. The case for considering such conduct under other statutory factors.

The Eighth Circuit's conclusion that prior conduct may not be considered part of a juvenile's prior record but may be considered under factors such as social background is not unpersuasive. The idea that district courts should be able to examine a number of different aspects surrounding a juvenile's life appeals to the old Progressive era presumption that courts, looking carefully at each individual, can make informed, appropriate decisions about each minor's fate. ${ }^{178}$

173 This is the point on which $L W O$ and In re Sealed Case agree. See LWO, 160 F3d at 1183 ("[T]he plain language of the term 'the juvenile's prior delinquency record' would not encompass evidence of incidents or behavior, which could be of a delinquent or criminal nature."). Wilson, $149 \mathrm{~F} 3 \mathrm{~d}$ at 613 , as discussed previously, extended this analysis to hold that prior arrests are also included. See Part IV.C. See also In re Sealed Case, 893 F2d at 369 \& n 12 (suggesting transferring courts may not consider uncharged conduct).

174 See, for example, United States v Dion L., 19 F Supp 2d 1224, 1226 (D NM 1998) (including school suspensions and expulsions "for using drugs and alcohol and for carrying a knife and scissors as weapons" under the prior record factor); United States v M.H., 901 F Supp 1211, 1215 (E D Tex 1995) (including under the prior record factor, evidence that a juvenile offender may have been involved in "two other uncharged robberies"); In re T.W., 652 F Supp 1440, 1444 (E D Wis 1987) (considering disciplinary problems at school as part of a juvenile record).

175 See, for example, Camitsch v Risley, 705 F2d 351,354 (9th Cir 1983) (noting various definitions of prior records and case files). See also notes 153-63 and accompanying text.

176 Ullman, Note, 68 Fordham L Rev at 1361 (cited in note 153).

177 But compare this conclusion with id at 1363 (urging Congress to revise Section 5032 so as to permit the consideration of "all prior police contacts").

178 See Section I.A (discussing the development of the Progressive idea). 
After all, some behavior that might be uncharged or unadjudicated criminal conduct clearly reflects on the character and mindset of a juvenile. ${ }^{\text {Th }}$ For instance, few people would likely contend that in a case like Anthony $Y$., where the minor's uncharged and unadjudicated conduct included destroying property, assaulting a counselor, and abusing drugs, the juvenile's history of uncharged "criminal" conduct should be ignored. ${ }^{1.00}$ It is, one can argue, exactly this type of evidence that juvenile courts are supposed to consider when deciding whether a "juvenile has a realistic chance of rehabilitative potential."

Beyond intuitions and commonsensical arguments, a strong legal argument exists for upholding the admission of "criminal-like conduct" under the social background, psychological maturity, or past treatment factors. ${ }^{18}$ It is difficult to deny that those terms, especially given the limited statutory guidance provided and the court's obligation to act in the interest of justice, invite broad interpretations. Moreover, it is, one could point out, important to keep in mind that evidence presented under Section 5032's non-legal factors (for example, social background and intellectual maturity) may be challenged by a juvenile at his transfer hearing. Consequently, one could argue, as the court in In re Sealed Case pointed out, that "if a juvenile [were] entitled to rebut the uncharged offenses at the transfer hearing, due process would not be an issue." charged conduct is no different than considering prior arrests: as long as the juvenile is able to challenge its probative value at a transfer hearing, the evidence should be considered.

Finally, supporters of the $L W O$ approach could claim that district courts considering uncharged offenses must still draw a connection between the alleged conduct and the Section 5032 factor under which it is considered. ${ }^{\text {IS }}$ That is, a juvenile might still appeal and challenge the consideration of past conduct where a court does not adequately link the conduct to the factor. Nor, one could point out, are district courts simply processing juveniles into the adult criminal justice system without reflection or consideration. They carefully weigh the evi-

179 See, for example, Uilman, Note, 68 Fordham L Rev at 1360-61 (cited in note 153) (arguing that since the purpose of the "federal juvenile justice system is to rehabilitate juveniles amenable to treatment," if a "juvenile shot a perfect stranger" but was never prosecuted for it, courts should still be able to examine such conduct).

180172 F3d at 1253.

181 United States v E.K., 471 F Supp 924, 932 (D Or 1979).

18218 USC $\$ 5032$.

183 In re Sealed Case, 893 F2d at 369 n 12.

184 See $L W O, 160$ F3d at 1183-84 (requiring a district court to explain "how the alleged incidents, behavior, charges, and surrounding circumstances are relevant to that factor"). 
dence presented, sort out irrelevant or minor past violations, and then decide if a transfer is warranted. ${ }^{18}$

\section{Considering uncharged conduct under other factors is inappropriate.}

While there are certainly good reasons to consider uncharged criminal conduct, to construe Section 5032 as permitting the consideration of "almost any action, criminal or otherwise, the juvenile has taken" ${ }^{186}$ sweeps too broadly. First, such an interpretation runs roughshod over the other statutory factors delineated in the FJDA. If Congress had intended the "social background" or "psychological development" prongs to encompass a juvenile's uncharged prior criminal conduct, why would it have found it necessary to draft an independent "prior delinquency record" factor? Had Congress intended such broad probing into almost every action ever committed by a juvenile, it could have simply enacted a statute requiring transfer "if it is in the interest of justice." It did not. To then read factors like "psychological background" so broadly, effectively negates the significance and meaning of the other transfer factors and violates the common canon of statutory construction "that a statute should be construed in such a way that no word, clause or sentence is rendered meaningless or superfluous." 188

While it is one thing to suggest that a transferring court must have broad discretion in deciding how to weigh factors for or against a juvenile's transfer, it is entirely another to suggest that determining what behavior falls under each factor is wholly discretionary. To read factors such as social background and psychological maturity too broadly ignores the fact that the 1974 FJDA amendments went be-

185 For cases bolstering this claim, see United States $v$ Leon, D.M., 132 F3d 583 (10th Cir 1997) (upholding district court's refusal to transfer seventeen-year-old minor charged with murder to adult status); United States v One Juvenile Male, 51 F Supp 2d 1094 (D Or 1999) (holding that prospect of rehabilitation warranted refusing to transfer minor charged with shooting two men and killing one); United States v Juvenile K.J.C., 976 F Supp 1219, 1228 (N D Iowa 1997) (concluding that minor vandalism of property did not weigh in favor of transfer).

186 LWO, $160 \mathrm{FBd}$ at 1183.

187 Such broad and unguided transfer statutes have survived constitutional challenges for being too vague and broad. See, for example, Donald L. $v$ Superior Court, 498 P2d 1098 (Cal 1972) (upholding statute that authorized transfer if court determined juvenile was not "fit" for juvenile court system). See also State v Gorzelanny, 468 NE2d 589, 590 \& n 4 (Ind App 1984) (noting that once a court determines there is probable cause that a juvenile committed a certain crime, and once the court determines the juvenile is over sixteen years of age, the only guidance Indiana law (in 1984) gave to a trial court in transferring a juvenile was whether a juvenile adjudication was in the child's and community's "best interest").

188 Holloway v J.C. Penney Life Insurance Co, 190 F3d 838, 843 (7th Cir 1999). See also Pennsylvania Medical Society v Snider, 29 F3d 886, 895 (3d Cir 1994) ("A statute should be construed so that effect is given to all its provisions, so that no part will be inoperative or superfluous, void or insignificant."). 
yond the holding of Kent and limited the type of areas a court could consider when making a transfer decision.

Moreover, to look at any type of uncharged, allegedly delinquent behavior sweeps in far too many cases. As one commentator observed, "researchers have learned that arrest statistics merely reflect the tip of the deviance iceberg ... Actual rates of illegal behavior soar so high during adolescence that participation in delinquency appears to be a normal part of teen life." some documentation and at least identify specific charges and, hopefully, the events surrounding them, prior "bad conduct" is so flexible a concept that it invites the inclusion of almost any behavior without a clearly identifiable limit. If such a reading could be applied to the Section 5032 factors, then the due process protections the six statutory factors were intended to provide juveniles ${ }^{191}$ would be destroyed. As one observer has noted, "The lack of uniformity in the federal approach to judicial waiver ... results in different dispositional outcomes for similarly situated offenders. . . . and therefore may result in violations of due process." ously uncharged conduct or undocumented police contacts, therefore, could invite unmonitored roving that could consume substantial resources $^{193}$ and allow almost every type of infraction to be reviewed. ${ }^{194}$

189 See S Rep No 93-1011 at 56 (cited in note 80) (noting Section 5032 was amended to provide "[s]pecific criteria . . . by which the court shall assess the prospects for rehabilitation"). A reading of the FJDA so that the factors it outlines are closely adhered to also seems to be in accordance with the statutory construction principle of expressio unius est exclusio alterius. See $\mathrm{Na}$ tional Railroad Passenger Corp v National Association of Railroad Passangers, 414 US 453, 458 (1974) ("A frequently stated principle of statutory construction is that when legislation expressly provides a particular remedy or remedies, courts should not expand the coverage of the statute to subsume other remedies."); Botany Worsted Mills v United States, 278 US 282, 289 (1929) ("When a statute limits a thing to be done in a particular mode, it includes the negative of any other mode."). Consequently, where the Congress has laid out the specific factors that a court must consider when deciding to transfer a minor, it can be argued that only those factors should be considered in making a transfer decision.

190 Terrie E. Moffitt, Adolescence-Limited and Life-Course-Persistent Antisocial Behavior: A Developmental Taxonomy, 100 Psych Rev 674, 675 (1993). See also Snyder and Sickmund, Juvenile Offenders at 51 (cited in note 1) ("Many offenders are not arrested; and many arrested are not referred to juvenile courts and, thus, are not captured in official law enforcement or court data.").

191 See Part III.

192 Ullman, Note, 68 Fordham L Rev at 1357-58 (cited in note 153).

193 See Wilson, 149 F3d at 613 (warning against proceedings where the government attempts to prove uncharged conduct through de facto trials that would "greatly burden the parties"). Admittedly, the Eighth Circuit did try to preempt such roaming by holding that the district court "should articulate the reasons for considering such evidence, and the manner in which such evidence bears upon the analysis of the factor." $L W O, 160 \mathrm{F3d}$ at 1184 . Such a check, however, would effectively allow a court to consider prior conduct so long as a reasonable explanation for the factor exists. Given the amount of discretion the Eighth Circuit affords to such interpretations, it would be very hard for the juvenile to overcome such a finding. 
Thus, a court should not be permitted to consider uncharged criminal conduct in making a transfer decision. Such an approach keeps the six statutory factors within reasonable bounds, while still permitting a court to make a largely discretionary transfer decision. After all, the age of the minor, the cruelty of the underlying conduct, prior record (narrowly defined), and psychological reviews all offer courts ample information without lurching toward an unfettered inquiry into putative criminal conduct from the past. It must also be kept in mind that individuals whom society might deem the most unworthy of a juvenile proceeding are automatically waived into criminal court. ${ }^{195}$

\section{CONCLUSION}

Issues of juvenile adjudication are increasingly important to courts at the federal level. As pressure grows to prosecute minors as adults, it is important to resolve recent disagreements over the extent to which a court may look at alleged prior criminal conduct. When determining what constitutes a juvenile's "prior delinquency record," precedent and statutory construction of the FJDA suggest it is appropriate for courts to consider the minor's prior unadjudicated arrests. However, the review of uncharged, allegedly criminal conduct is beyond the statutory factors outlined in the FJDA, and accordingly, courts should not consider such conduct as part of a juvenile's "prior record" or under any of the other FJDA factors.

194 For an example, see United States v Dion L., 19 F Supp 2d 1224, 1226 (D NM 1998) (considering suspensions and expulsions from school for using drugs and alcohol as part of the juvenile's prior record).

195 See 18 USC $\S 5032$ (providing that if a juvenile is previously found to have violated a law and is alleged to have committed certain violent crimes or narcotic offenses, he is automatically waived into criminal court). 